\title{
PROBLEMATIZANDO OS SENTIDOS DE ÉTICA DO ESCOLA SEM PARTIDO: \\ UMA BREVE ANÁLISE DE ENTEXTUALIZAÇÕES DO PROGRAMA SOBRE UMA PRÁTICA DOCENTE
}

Tarcísio da Silva Nicácio*

\section{Resumo}

O presente artigo problematiza os sentidos construídos pelo alegadamente apartidário programa "Escola sem Partido" sobre o exercício de ética de uma prática docente. Assim, alinho-me a um sentido de educação ético-política e anti-hegemônica (FREIRE, 2006; 2013; MOITA LOPES, 2006; hooks $^{1}$, 2013) em meio à era da pós-verdade (CIAVATTA, 2017). A análise qualitativa enfoca o uso da linguagem como fenômeno textual, constantemente envolvido em processos de entextualização (BAUMAN; BRIGGS, 2006). Resultados apontam que o programa compartilha sentidos de ética fundados no medo, na acriticidade, na ameaça, na censura em benefício de uma linha partidária.

\section{Palavras-chave}

Ética. Educação. Entextualização. Escola sem Partido, Era da Pós-Verdade.

\begin{abstract}
Sentimos a necessidade de uma reflexão ética mais profunda quando nos defrontamos com dilemas, com situações de conflito, diante dos quais temos de decidir e vemos que nossa decisão não é fácil. Precisamos refletir, buscamos justificativas para uma posição ou outra, procuramos critérios em que possamos nos basear para tomar nossa decisão.

MARCONDES, 2007, p. 11.
\end{abstract}

\section{1) Introdução}

Se há uma oportuna consideração suscitada pelo chamado programa Escola Sem Partido (doravante, ESP) - a qual deve ser pauta de muita reflexão e muito debate por todos aqueles que defendem uma educação como prática da liberdade - esta é consoante ao entendimento de ética na prática docente. Concebida como um valor

\footnotetext{
*O autor é mestrando em Estudos da Linguagem na Pontifícia Universidade Católica do Rio de Janeiro e bolsista CAPES. É graduado em Letras (Português/Inglês - Licenciatura) pela Universidade Federal do Rio de Janeiro. Suas áreas de interesse abarcam Linguística Aplicada, Ensino/Aprendizagem de Línguas, Discursos midiáticos e Afeto numa perspectiva discursiva.

${ }^{1}$ bell hooks prefere referenciar seu pseudônimo, inspirado em sua bisavó materna, em letras minúsculas por considerar que é a construção do conhecimento e do ativismo de suas obras que deve ocupar uma centralidade discursiva.
} 
primordial e norteador de decisões e de práticas interpessoais, a ética é buscada em diferentes âmbitos, sobretudo em situações complexas para as quais geralmente não cabem respostas simples.

Conforme bem problematiza Marcondes (2007), a discussão em torno desse assunto não se apresenta facilmente, uma vez que pensar o conceito de ética é explorar noções de certo ou de errado sócio-historicamente estabelecidas e remodeladas de acordo com novas mudanças de paradigma em uma determinada sociedade ou grupo social. Nesse sentido, o valor ético possui um viés restritivo nos caminhos da liberdade do pensar e do agir do indivíduo, isto é, no seu dever para com o outro na coletividade.

É razoável reconhecer também a coexistência de mais de uma ideia de ética na medida em que particularidades socioculturais subjazem a interpretação de certos parâmetros tidos como éticos. Assim, vozes afinadas ou não aos discursos do ESP tanto prezam quanto discordam dos sentidos construtores de uma agenda ética no exercício da profissão docente. Contudo, indaga-se: seria uma medida ética, por exemplo, intimidar a prática de uma professora ou, ainda, tecer sérias imputações de transgressão ética a seu respeito sem embasamento ou sem respaldo constitucional que sustente tais alegações? Sem aquiescência da professora no que tange à gravação e à publicidade de suas falas em sala de aula para uma plataforma que se assemelha a um dispositivo de "caça às bruxas" da contemporaneidade?

Essa problemática seria uma situação absurdamente hipotética se não se tratasse de um caso concreto associado ao contexto de uma escola estadual em um município de Santa Catarina. O caso foi publicado na plataforma digital do ESP, em 2018, sem indicação de data, sob o título "Flagrante de doutrinação em escola de Santa Catarina mãe de aluna denuncia e comprova conduta covarde, antiética e abusiva da professora de história" (grifo meu). Ele foi acompanhado da publicação de um vídeo no qual a mãe em questão, juntamente ao irmão da aluna, acusam uma professora de História de “doutrinação ideológica”, após procederem a uma gravação não autorizada da docente no exercício de sua prática profissional.

Diante de tal panorama, neste estudo proponho uma análise qualitativointerpretativista em torno dos sentidos construídos pelo alegadamente apartidário programa "Escola sem Partido" sobre o exercício de ética de uma prática docente. Para tanto, operacionalizo a noção de processos de entextualização (BAUMAN; BRIGGS, [1990] 2006; BLOMMAERT, 2005) como aporte analítico a fim de entender como os territórios escolar e familiar são entextualizados à medida que a ética profissional de 
uma docente é posta em questão. Os dados gerados reconstroem parte da trajetória textual disseminada pelo ESP, com foco no site de divulgação e no citado vídeo utilizado como ferramenta de denúncia pelos seus organizadores.

A condução do presente estudo reside no meu interesse de criar maior entendimento sobre o uso da linguagem como parte constitutiva da relação entre educação, ética e política. $\mathrm{Na}$ posição assumida de professor-pesquisador, espero contribuir para a produção epistemológica de uma linha de autoras e de autores a favor de uma educação mais democrática, multicultural e aberta ao pluralismo ético de ideias, práticas e identidades (FREIRE, [1970] 2006; [1996] 2013; FABRÍCIO; MOITA LOPES, 2002; CANDAU, 2008; hooks, 2013, entre outras vozes). Assim, não pressuponho neutralidade discursiva, pois o sentido de "realidade" aqui é inarredavelmente sustentado por um ponto de vista. Tal como Kumaravadivelu (2006), não me baseio em uma concepção de textos como manifestações neutras ou ideologicamente vazias, uma vez que "os textos são políticos porque todas as formações discursivas são políticas. Analisar texto ou discurso significa analisar formações discursivas essencialmente políticas e ideológicas por natureza" (KUMARAVADIVELU, 2006, p. 140).

No desenvolvimento deste artigo, apresento uma breve revisão da trajetória do chamado Programa Escola sem Partido. Nesse intento, articulo algumas visões especializadas nas áreas de Educação, História e Filosofia com relação aos efeitos insidiosos dessa organização que se lança como apartidária, mas que possui um forte vínculo institucional com representações políticas, denominações religiosas e ideologias (crenças, ideias, visões) bem delimitadas.

\section{2) Escola sem Partido: formação, crenças e desdobramentos}

Tendo seu início em 2004, o chamado programa Escola sem Partido foi inspirado - segundo palavras de seu coordenador, o advogado Miguel Nagib, na seção "Quem Somos" do site ${ }^{2}$ — numa "bem sucedida experiência" estadunidense intitulada Noindocrination.org. O objetivo compartilhado, conforme a seção "Objetivos" do site, é o de "dar visibilidade a um problema gravíssimo que atinge a imensa maioria das escolas e universidades brasileiras: a instrumentalização do ensino para fins políticos,

\footnotetext{
${ }^{2}$ A listagem completa do endereço dos sites se encontra nas Referências bibliográficas.
} 
ideológicos e partidários". De livre acesso, o site do ESP atua como uma forma de difundir crenças e instrumentos que orientem pais e alunos a identificar, a flagrar e a denunciar o que a organização concebe como "práticas de doutrinação ideológica". Segundo esse canal, figurariam entre tais práticas situações nas quais o professor "se desvia frequentemente da matéria objeto da disciplina para assuntos relacionados ao noticiário político ou internacional" e "adota ou indica livros, publicações e autores identificados com determinada corrente ideológica", explica o programa na seção "Flagrando o doutrinador".

Ao longo dos anos, o ESP vem ganhando bastante visibilidade e adesão. Se em 2004 as redes sociais não cumpriam um papel decisivo na dinâmica do debate público, hoje até o atual Presidente do Brasil, Jair Bolsonaro, utiliza sua conta oficial no Twitter como principal veículo de informações e opiniões sobre uma série de tópicos, relevantes ou não tão $\operatorname{assim}^{3}$, para sua gestão à frente do nosso país. Sua dura afirmação de que é preciso "expurgar a ideologia de Freire”, repercutida não apenas em mídias jornalísticas (como GOIS, 2018), mas também em sua proposta de governo, encontrada no site do TSE, é um forte indício da aderência discursiva do ESP ao debate público atualmente. Tal como o presidente, o programa menoscaba a importância atribuída à pedagogia freireana, com base nas considerações ${ }^{4}$ do pensador Olavo de Carvalho.

No que tange à família Bolsonaro, Espinosa e Queiroz (2017) verificam uma ativa participação de Carlos Bolsonaro e Flávio Bolsonaro (vereador e deputado estadual pelo Rio de Janeiro, respectivamente) no encaminhamento de projetos de lei a Casas Legislativas para inserir as propostas do ESP no âmbito educacional. Os autores também destacam o apoio de políticos vinculados à chamada bancada evangélica congressista, dentre os quais eles apontam os deputados Izalci (PSDB/DF), Erivelton Santana (PSC/BA) e Antônio Carlos Martins de Bulhões (PRB/SP), que também propuseram projetos de lei escorados no ESP. Tais ramificações religiosas e conexões políticas levam os autores a assinalar que "quem está dominando as pautas são os setores ultraconservadores e aqueles ligados fortemente a setores evangélicos, defensores dos valores que denominam da 'família tradicional' (...)". (ESPINOSA; QUEIROZ, 2017, p. 60).

\footnotetext{
${ }^{3}$ Algumas leituras de suas postagens podem ser ilustrativas. Conf. AGÊNCIA ESTADO (2019) e G1 (2019).

${ }^{4}$ Conf. "Viva Paulo Freire!”, no site do ESP.
} 
A fim de compreendermos as grandes proporções tomadas por esse programa, Penna (2017) nos insta a observar o estilo de linguagem empregado pelo ESP, que beira a um uso que classifica de senso comum. Como bem avalia o autor, seus idealizadores recorrem a "dicotomias simplistas que reduzem questões complexas a falsas alternativas e valendo-se de polarizações já existentes no campo político para introduzi-las e reforçá-las no campo educacional" (PENNA, 2017, p. 35). Com base em excertos extraídos de reportagens e de artigos que constam no próprio site, Penna também identifica quatro linhas de agência do ESP que atuam para o esfacelamento progressivo da liberdade de ensinar, a saber: (i) uma concepção de educação como escolarização, em que o professor não é educador, mas apenas um instrutor; o que resulta em sua (ii) desqualificação profissional, regida principalmente por (iii) estratégias discursivas fascistas, que lançam sobre o imaginário social a figura do professor como membro de uma suposta conspiração orquestrada pelo Partido dos Trabalhadores (PT); tais asserções criam um sentido de suspeição e, assim, o programa urge a "defesa do poder total dos pais sobre seus filhos" (PENNA, 2017, p. 36).

Tendo em vista essa teia de relações, é fundamental chamar a atenção para os efeitos de uma era que vem sendo interpretada como "pós-verdade". No contexto de avanços progressivos da tecnologia e da interatividade, a era da pós-verdade sinaliza uma forte tendência de validação de "rumores e opiniões que ajudam na difusão de inverdades e na organização das forças sociais com base em suposições" (CIAVATTA, 2017, p. 9), em detrimento de produção de verdades de base acadêmico-científicas. Nesse ritmo vertiginoso e acrítico, acredito que um valor importante como o da ética tende a ser banalizado conforme critérios de verdade vêm sendo avaliados em termos de especulações. O uso de "antiética" pelo ESP para qualificar a conduta de uma professora, a meu ver, parece ser um caso ilustrativo de tal risco de banalização. Portanto, é atento aos efeitos de sentido da referida qualificação que encaminho as subsequentes considerações, análises e reflexões propositivas.

\section{3) Breves considerações sobre ética: um construto social, histórico e cultural}

Referenciado na epígrafe deste trabalho, Marcondes (2007) oferece um interessante horizonte de perspectiva acerca de ética. Tida como um dos tradicionais conceitos discutidos no ramo da Filosofia, o autor sugere ser apressada a premissa de que a discussão deve se dar exclusivamente num plano teórico de ideias para só se 
pensar numa situação concreta a posteriori. Pelo contrário, ser ético ou antiético produz implicações muito importantes na vida das pessoas de modo que a teoria não deve ser afastada da prática.

Uma autoridade política desviou dinheiro público em benefício próprio, um cliente percebeu ter recebido o troco a mais do caixa e nada falou, uma escolha de palavras foi capaz de ferir a dignidade de alguém, essas situações são práticas cotidianas que não devem prescindir de avaliações éticas. Contudo, se não há um sentido simples e definitivo de ética, como proceder diante de tais condutas? Como caracterizar o exercício da ética?

A fim de criar inteligibilidade sobre tais questões, recorro às três dimensões apresentadas por Marcondes (2007), mediante as quais seria possível conceber a ideia de ética. A primeira se relaciona a um sentido básico ou descritivo, análogo à significação originária grega de ethos, referente ao conjunto de hábitos e costumes de um povo. Em outras palavras, há aqui uma espécie de acordo tácito, no qual a ética é um princípio incutido mediante a observação de exemplos de conduta praticados pelos próprios membros de um grupo. Já a segunda possui um valor normativo, isto é, de cima para baixo, como preceitos que instituem e que justificam valores a serem seguidos (vide dogmas religiosos ou códigos profissionais de ética). A terceira, por sua vez, caracteriza-se por um viés reflexivo ou metaético, no sentido de discutir e de avaliar pressupostos que fundamentam teorias ou perspectivas filosóficas de ética.

O autor nos remete também a outros filósofos postuladores de conceitos de ética, dentre os quais ele destaca a chamada universalidade ética kantiana. Segundo ele, Kant preconiza a universalidade como um critério fundamental para avaliar o caráter ético de um ato. Nessa linha de pensamento, um ato pode ser considerado ético se a pessoa que o cometeu concordar em receber o mesmo tipo de tratamento de outro indivíduo. Destarte, não é cabível uma espécie de ética que faça distinção de pessoas. Ela deve ser aplicável a todos a despeito de quaisquer achismos de superioridade. Discurso e prática devem andar lado a lado em benefício de um exercício ético coerente.

Dado o escopo deste artigo, não discorro exaustivamente sobre diferentes perspectivas filosóficas atinentes à ética. Nos termos de Marcondes (2007, p.11), é pertinente focalizar o modo pelo qual os participantes formulam e direcionam a discussão de questões éticas - foco na terceira dimensão: reflexiva ou metaética. Assim, vale compreender como tal discussão circula pelos territórios escolar e familiar tendo 
em vista os sentidos construídos pelo ESP e por membros de uma família alinhada ao programa sobre a conduta de uma professora em sala de aula.

Na seção seguinte, saliento o que podemos entender por defesa de uma agenda ético-política e anti-hegemônica. Dentre as vozes articuladas, figura a de Paulo Freire, cuja pedagogia é menosprezada pelo ESP e seus associados, como exposto anteriormente. A discussão de ética será apresentada sob o pano de fundo da relação professor-aluno, numa perspectiva alimentada pelas ideias freireanas.

\section{4) A indissociabilidade da ética na prática docente-discente}

É impossível, na verdade, a neutralidade na educação. E é impossível não porque professoras e professores "baderneiros" e "subversivos" o determinem. A educação não vira política por causa da decisão deste ou daquele educador. Ela é política. Quem pensa assim (...) não pode esconder a forma depreciativa como entende a política. (...) A raiz mais profunda da politicidade na educação se acha na educabilidade mesma do ser humano. (...) Inacabado e consciente de seu inacabamento, histórico, necessariamente o ser humano se faria um ser ético, um ser de opções, de decisão. Um ser ligado a interesses e em relação aos quais tanto pode manter-se fiel à eticidade quanto pode transgredi-la. (FREIRE, [1996] 2013, p. 108, grifo do autor).

Trago Freire ([1996] 2013) à discussão por suas importantes considerações acerca da responsabilidade inseparavelmente ética, política e intervencionista da educação. Uma delas está na necessidade de tomada de decisões inerente ao trabalho docente. A construção do conhecimento - diferentemente de transferência ou depósito, como o próprio autor assevera (FREIRE, [1970] 2006) — deve envolver um criterioso e responsável processo de escolha, abordagem de temas e questões sociais, políticas, culturais, tomando o grupo discente como parte igualmente construtora desse desenvolvimento. Se há uma escolha, ela não pode ser neutra por renunciar a outras possibilidades.

Fiar-se numa defesa de neutralidade docente é esvaziar terminantemente o papel do professor como educador, reconstruindo-o como um reprodutor de instruções préconcebidas. O docente é então impedido de atuar com bom senso na avaliação do seu contexto e realizar quaisquer intervenções que julgar necessárias tendo em vista as especificidades de seu grupo discente. No entanto, uma agenda ético-política e antihegemônica clama não só o reconhecimento dos atravessamentos identitários constitutivos do inacabamento histórico de docentes e discentes, mas também o repúdio 
de qualquer violência física ou simbólica contra vidas postas à margem, as quais Moita Lopes (2002 apud 2006) descreve com a ressalva de não essencializá-las: "os pobres, os favelados, os negros, os indígenas, homens e mulheres homoeróticos, mulheres e homens em situação de dificuldades e outros" (MOITA LOPES, 2006, p. 86).

Moita Lopes (2006) destaca também o fato de a ética ser pauta das ciências sociais, especialmente quando se reconhecem a alteridade e heterogeneidade atreladas à construção do saber. Assim como Freire, ele não acredita numa defesa indistinta de quaisquer posições discursivas. Para ele, ser ético é necessariamente excluir significados geradores de dor e de sofrimento humano. Em linha transgressiva semelhante segue bell hooks (2013), que acredita haver muita potência no entusiasmo como forma de experiência coletiva e libertadora, desde que pautado por incessantes reflexões que reconheçam alunas e alunos como "seres humanos integrais, com vidas e experiências complexas, e não meros buscadores de pedacinhos compartimentalizados de conhecimento" (hooks, 2013, p. 27).

A agenda de epistemologias anti-hegemônicas deve, por conseguinte, ser responsiva a tal decisão ética e também política. Para tal empreendimento, é necessária uma perspectiva de linguagem e de texto como elementos não representativos, mas sim construtores de dinâmicas sociais e de produção de saberes. Na seção seguinte, discorro sobre a potencialidade de considerar processos de entextualização (BAUMAN; BRIGGS, [1990] 2006; BLOMMAERT, 2005) como ferramenta analítica pertinente ao dinamismo atribuído à linguagem e ao texto.

\section{5) Processos de entextualização}

Na perspectiva de Bauman e Briggs ([1990] 2006), o entendimento de processos de entextualização requer um distanciamento da noção de texto como um artefato puramente linguístico, isolado e referencial. Concebê-lo dessa forma seria o mesmo que acreditar que ele apenas refletiria o mundo. Afastando-me dessa visão de linguagem e texto, percebo-os como atividades dinâmicas, variáveis e permeadas por uma gama de ideologias que ajudam a construir práticas e relações sociais.

No que se refere à entextualização, a compreensão da ideia de performance é indispensável. Na contramão do que a tradição ocidental conceptualiza como "usos habilidosos da linguagem", Bauman e Briggs ([1990] 2006) consideram que performance é um fazer epistemológico produtor de visões sobre processos 
comunicativos. Segundo os autores, "[u]ma dada performance está ligada a vários eventos de fala que a procedem e a sucedem (performances passadas, leituras de textos, negociações, ensaios, fofoca, relatos, críticas, desafios, performances subsequentes (...))" (BAUMAN; BRIGGS, [1990] 2006), p. 189).

Ante ao exposto, analisar criticamente uma performance é vislumbrar que, apesar de ela estar situada em um evento comunicativo específico, não se circunscreve tão-somente a ele (i.e, um constante fazer, não uma essência imanente), mas remonta a uma história de usos e crenças em trajetória sócio histórica. Os autores salientam que essa mobilidade não é resultante do contexto em que uma comunicação acontece. $\mathrm{Na}$ verdade, ela decorre das negociações de significados por participantes de uma dada interação. Desse modo, em vez de persistirem com a noção de contexto, autores da antropologia linguística (BAUMAN; BRIGGS, [1990] 2006; BLOMMAERT, 2005, entre outros) focalizam processos de contextualização justamente para abarcar esse trabalho coletivo de produção de significados, no qual o contexto é um dos elementos — não o principal - que contribuem para essa negociação. A contextualização é, pois, um trabalho dialógico (BLOMMAERT, 2005).2

Portanto, a entextualização é um fenômeno performativo, um "processo de tornar o discurso passível de extração, de transformar um trecho de produção linguística em uma unidade - um texto - que pode ser extraído de seu cenário interacional" (BLOMMAERT, 2005, p. 206, grifo do autor). Logo, tal processo está imbricado com movimentos constantes de descontextualização e recontextualização, isto é, de deslocamento de textos para novos contextos interativos, com novos elementos e produtores de sentidos, sendo constantemente recontextualizados.

À guisa de exemplo, trago novamente à discussão o título do vídeo compartilhado pelo ESP: "Flagrante de doutrinação em escola de Santa Catarina - mãe de aluna denuncia e comprova conduta covarde, antiética e abusiva da professora de história". Os usos de "covarde", "antiética" e "abusiva" são modos de entextualização de como o programa e seus seguidores ressignificam a performance da professora ou seus efeitos geradores de sentido em termos de uma série de semioses implicadas: o contexto da sala de aula, o tema político em debate, as expectativas e pressupostos tanto do ESP como da mãe em relação ao que entendem por escola e prática docente. Logo, os sentidos se enredam em uma teia de significados compartilhados socialmente. Nessa perspectiva, a linguagem é tida como prática social na medida em que seus sentidos são negociáveis e produtores de (re)ações em sociedade. 
Ademais, Blommaert (2005) chama a atenção para os constantes fluxos de pessoas, crenças, significados que dinamizam a vida social. Como sugere o autor, a circulação de diversas semioses pode até preservar formas anteriores destas, mas está sujeita a outras produções de sentido orientadas por diferentes critérios de verdade e de hierarquização. Dito de outro modo, guiadas pelo que o autor assinala como ordens de indexicalidade. Estratificação é um elemento-chave para se entender essa noção indexical. O autor aponta para o fato de que nossos repertórios de sentidos são valorados assimetricamente em diferentes espaços por que circularmos, bem como o reflexo de uma sociedade estratificada por diversas classes e discursos.

Portanto, acredito que a linguagem assume um papel primordial na construção da vida social. Em outras palavras, entendo o uso linguístico como prática social e estou interessado nos efeitos implicados em relações intersubjetivas. Ademais, não busco teorizar sobre uma ideia de essência ética de virtudes humanas. O construto da entextualização diz respeito a uma prática coletiva de negociação e ressignificação de discursos, não a uma característica imanente do sujeito.

\section{6) Contextualização da análise e da geração dos dados}

Focalizo a publicação de um vídeo de acesso público, compartilhado em "Flagrante de doutrinação em escola de Santa Catarina", uma das páginas da plataforma online do programa Escola Sem Partido. A escolha investigativa se justifica pelo meu repúdio ao caráter cerceador e pretensamente neutro do programa que se autoafirma como apartidário. Na discussão dos meus dados, opto por uma reflexão metaética sobre a escolha e efeitos de sentido da palavra "antiética" pelo ESP para qualificar uma prática docente. Como expus anteriormente, acredito ser imprescindível a revisitação de certos conceitos suscetíveis à banalização na era da pós-verdade.

Os dados gerados para a condução deste estudo qualitativo reconstroem parte das entextualizações do ESP a respeito de ética na educação. O método de geração empregado compreende: (i) algumas descrições textuais presentes ao longo do site ESP; (ii) transcrição livre das falas da mãe e do irmão da aluna no vídeo cuja integralidade perfaz um total de oito minutos e quinze segundos (dos quais só transcrevo três minutos e sete segundos consoante às falas mencionadas). O restante do vídeo se presta à gravação não autorizada da professora, motivo pelo qual tal parte não será esquadrinhada neste estudo. 
É importante salientar que as categorias "mãe", "filho/a", "aluna" serão mantidas na explanação das minhas análises como uma forma de questionar o próprio conceito de família que emerge do discurso do ESP. Ademais, com o intuito de contextualizar o referido locus investigativo, destaco um excerto presente na seção "Quem somos" do site do ESP: "[o]correu-nos, então, a ideia de divulgar testemunhos de alunos, vítimas desses falsos educadores. Abrir as cortinas e deixar a luz do sol entrar. (...)". Aqui, a entextualização de alunos como "vítimas" indicia (BAUMAN; BRIGGS, [1990] 2006; BLOMMAERT, 2005) um esfacelamento das relações de confiança entre professor, aluno e família. É fundamental considerar que, no processo de ensino-aprendizagem, a relação de confiança é a base para a construção do conhecimento escolar (FREIRE, [1970] 2006; [1996] 2013; hooks, 2013). Minha análise está subdivida em quatro eixos temáticos, a saber (i) o título-denúncia do vídeo compartilhado: uma ética amedrontadora; (ii) escola como um espaço não reflexivo: uma ética acrítica; (iii) discordância como rivalidade: uma ética ameaçadora e (iv) o crime é discordar do "meu partido": uma ética censuradora.

\section{7) Análise dos dados}

\section{Eixo 1 - O título-denúncia do vídeo compartilhado: uma ética amedrontadora}

Em se tratando do vídeo, a linha criminalizadora adotada pelo ESP, sobre a qual comecei a discorrer anteriormente, é também verificada no modo pelo qual o vídeo propalado é entextualizado: "Flagrante de doutrinação em escola de Santa Catarina mãe de aluna denuncia e comprova conduta covarde, antiética e abusiva da professora de história". É flagrante o sentido de ameaça que busca reforçar aqui traços de um suposto crime cometido. O vídeo assume contornos de queixa-crime haja vista o forte caráter de denúncia indiciado pelo uso de "flagrante". Tal escolha de palavra entextualiza (BAUMAN; BRIGGS, [1990] 2006; BLOMMAERT, 2005) a aula da professora como a perpetração de um crime sorrateiro, sendo seus alunos reconstruídos como vítimas destituídas de qualquer forma de resistência. Ela é lida como autora de um crime doutrinário, capaz de "transmitir" ideologias que atentam contra a mente passiva de seus alunos, que estão sob o risco de reproduzirem o que ela afirmar.

As escolhas "denuncia" e "comprova" realçam ainda mais o significado de poder de polícia entextualizado pelo ESP. Além de uma forma de se resguardar e provar a acusação imputada - isto é, tanto o ESP quanto a mãe parecem ter ciência de sua grave 
alegação - o uso de "comprova" pode indiciar também uma ideia pré-concebida sobre a prática da professora. Nesse sentido, se há uma expectativa de que se comprove algo, é possível que haja desde já uma desconfiança para a qual não havia provas ainda. A esse respeito, a professora é mais uma vez entextualizada (BAUMAN; BRIGGS, [1990] 2006; BLOMMAERT, 2005) como criminosa e, por esse motivo, seria cabível a gravação de áudio sem o seu conhecimento. Para o ESP, o sentido de ética (MARCONDES, 2007) está em denunciar um suposto crime, não em gravar a fala da professora sem seu prévio consentimento.

Com base nesse primeiro eixo analítico, verifico que, à medida que o discurso da professora é valorado como criminoso - reforçado pelas entextualizações (BAUMAN; BRIGGS, [1990] 2006; BLOMMAERT, 2005) “covarde, antiética e abusiva” —, a concepção de ideologia é negativamente recontextualizada: um conjunto de crenças falseadoras que desvirtuam a "realidade" de um caminho idealizado de objetividade e de neutralidade. A professora, por sua vez, acaba por ter sua ética questionada sob o signo do medo por ter sua aula vigiada para fins de suspeita de crime.

Procedo, então, à análise dos sentidos construídos na interação entre mãe e filho, no vídeo compartilhado pelo ESP. Nesse caso, não há uma preocupação por parte do próprio programa em contextualizar as identidades socioculturais dos participantes envolvidos (FREIRE, [1970] 2006; [1996] 2013; MOITA LOPES, 2006). Contudo, poder-se-ia contra-argumentar que a lógica do ESP busca preservar o anonimato das supostas "vítimas", o que seria problematizável já que a "acusação" foi divulgada em vídeo. Em outras palavras, qualquer tentativa de denúncia em caráter anônimo "cai por terra", porquanto o ESP expõe não somente a figura da professora de História, como também dos membros da família em questão. Além disso, as menções singulares das categorias "mãe" "filha/o", "aluna" acabam por evocar uma espécie de crime atentado a um modelo de unidade familiar, sendo uma estratégia — diante das considerações tecidas (MARCONDES, 2007; ESPINOSA; QUEIROZ, 2017) - antiética e inconsistente de corresponder a uma alegação de "neutralidade".

\section{Eixo 2 - Escola como um espaço não reflexivo: uma ética acrítica}

\begin{tabular}{|c|l|l|l|}
\hline Mãe & 1 & Eu to gravando esse vídeo aqui porque eu to indignada. A minha filha \\
& 2 & chegou da escola agora. Ela estuda na Escola, ali, Estadual Dra. Naya \\
& 3 & Gonzaga Sampaio, aqui de Caçador, Santa Catarina. Então, é o seguinte, que \\
& 4 & a professora de História, hoje, que era pra dar História, né, seria o correto, \\
& 5 & né, o certo, que ela [a filha] tá lá pra aprender História, Geografia, \\
& 6 & Matemática, Inglês, Português, né. Mas a professora deu uma aula e uma \\
\hline
\end{tabular}




\begin{tabular}{|c|c|l|}
\hline & & aula mentirosa... \\
\hline Irmão & 7 & E não é aula de História. É aula partidária. É pelo um partido e você sabe \\
& 8 & como é, né? \\
\hline Mãe & 9 & Professora esquerdista, né, que pra ela o Lula é inocente, que o PSOL, PC do \\
& 10 & B e PT as melhores coisas do mundo que aconteceu no Brasil. E ela tá lá, \\
& 11 & deu uma aula totalmente incitando o ódio, eles que falam tanto de \\
& 12 & preconceito. Primeiro contra cristãos, contra a bíblia e depois dizendo que se \\
& 13 & Bolsonaro ganhar, ele vai pegar e botar todos os negros de volta na senzala, \\
& 14 & ou seja, Bolsonaro vai a trazer a escravidão de volta pro Brasil, né, que é \\
& 15 & 80\% do Brasil é negro e 72\% mulheres e que o Bolsonaro vai trazer a lei do \\
& 16 & estupro, ou seja, que as mulheres vão ser liberadas pra ser estupradas \\
\hline Irmão & 17 & Qualquer homem vai poder fazer o que quer na rua e isso é o que eles tão \\
& 18 & falando né... \\
\hline
\end{tabular}

A mãe e seu filho atuam conjuntamente na recontextualização (BAUMAN; BRIGGS, [1990] 2006; BLOMMAERT, 2005) da aula da professora. Por recontextualização quero enfatizar a prática de negociação de sentidos acerca do que eles concebem e compartilham como um exemplo de "aula-padrão". A ideia de padronização é indiciada pelo uso de "seria o correto, né, o certo" (1. 4-5) e não está circunscrita apenas à disciplina escolar de História, mas perpassa as abordagens de “Geografia, Matemática, Inglês, Português, né” (1. 5-6). Em tais passagens, uma prática caracterizada como aula deve corresponder a um modelo pré-fabricado de disciplinas a ser consumido por alunos-depósitos, o que vai de encontro a uma ideia de educação como prática ético-política (FREIRE, [1970] 2006; [1996] 2013; MOITA LOPES, 2006; hooks, 2013). Assim, diante de tais indexicalizadores (BLOMMAERT, 2005), pouco importa a área do conhecimento em pauta, pois valoriza-se uma postura docente ética reprodutora e acrítica em detrimento de uma prática dialógica e reflexiva. Em outras palavras, qualquer membro docente poderia lecionar qualquer matéria, desde que "transfira" o "conteúdo" pronto e programado. É de se perguntar, porém, se há qualquer embasamento teórico-prático para tal defesa de ensino conteudista ou se ela é calcada em considerações especulativas e sensacionalistas (CIAVATTA, 2017).

Posteriormente, as feições dessa prática conteudista tornam-se mais patentes quando analisamos os signos indexicais em referência à professora, ao ex-presidente do Brasil e a partidos políticos de esquerda em "Professora esquerdista, né, que pra ela o Lula é inocente, que o PSOL, PC do B e PT as melhores coisas do mundo que aconteceu no Brasil" (1.9-10). Ao entextualizar a professora como "esquerdista", a mãe nos remete a um sentido negativamente compartilhado no debate público sobre a orientação partidária à esquerda. O sentido negativo remonta a uma trajetória textual de discursos que dividem e rivalizam esquerda e direita partidárias, bem como apontam as anteriormente citadas 
declarações do então candidato à presidência, Jair Bolsonaro, em seu projeto de governo, e em outras mídias a respeito do que ele chama de "expurgar a ideologia de Freire”, um educador cuja posição política era declaradamente à esquerda. Aliás, a figura de Bolsonaro emerge logo em seguida como contraponto ao que é entextualizado como mentiras da esquerda: "Primeiro contra cristãos, contra a bíblia e depois dizendo que se Bolsonaro ganhar, ele vai pegar e botar todos os negros de volta na senzala, ou seja, Bolsonaro vai a trazer a escravidão de volta pro Brasil, né, que é $80 \%$ do Brasil é negro e $72 \%$ mulheres e que o Bolsonaro vai trazer a lei do estupro, ou seja, que as mulheres vão ser liberadas pra ser estupradas" (1. 12-16) e "Qualquer homem vai poder fazer o que quer na rua e isso é o que eles tão falando né...." (1. 17-18). A defesa partidária ao então candidato Bolsonaro é construída em oposição direta à figura do ex-presidente Lula (1.9), o que nos leva à acirrada corrida eleitoral de 2018 e a incerteza quanto à candidatura de Lula por sua condição judicial, indexicalizada pelo uso de "inocente" em "pra ela [a professora] o Lula é inocente" (1. 9).

Ante ao exposto, as críticas da mãe e do filho quanto ao conteúdo da aula são explícita e ideologicamente orientadas (KUMARAVADIVELU, 2006), pois indexicalizam discursos de base cristã e político-partidária. A escola é entextualizada como um espaço avesso ao debate de questões políticas. Nessa mesma linha, política e história são vistas como temáticas a ser abordadas, curiosamente, de modo estanque em sala de aula. A propósito, menções a casos de violências sistemáticas, tais como a escravidão, ou práticas análogas, e o estupro de mulheres são apenas desacreditadas. Não há reconhecimento ou problematização de tais questões por parte dos membros da família sob escrutínio, sendo elas recontextualizadas como especulações mentirosas da esquerda.

Por outro lado, com base em "ela tá lá, deu uma aula totalmente incitando o ódio, eles que falam tanto de preconceito" (1. 10-12), a preocupação maior dessa mãe volta-se para um possível clima hostil em sala de aula, com posições declaradas e discordantes, sobretudo por parte da professora. No entanto, a plausibilidade de tal argumento é desafiada se consideramos o canal mediante no qual esse vídeo é veiculado, seus propósitos e efeitos de sentido, como será analisado a seguir.

\section{Eixo 3 - Discordância como rivalidade: uma ética ameaçadora}

\begin{tabular}{|c|c|l|l|}
\hline Mãe & 19 & É o que essa professora fala, que a aula que ela deu é... tentando né, mexendo \\
& 20 & na cabecinha dele, de criança e adolescente entre treze e quinze anos né. E eu \\
& 21 & já falei com a diretora da escola ano passado por duas vezes. Eu to gravando \\
\hline
\end{tabular}




\begin{tabular}{|l|l|l|}
\hline & 22 & esse vídeo e eu vou tomar as providências legais contra essa professora \\
23 & porque ela tá lá pra ensinar a matéria. Ela não tá lá pra fazer campanha \\
24 & política e mesmo nós que somos cristãos de direita, né, nós procuramos \\
25 & respeitar a opinião das pessoas. E escola é o lugar pra o aluno ser ensinado, \\
26 & né, intelectualmente, não pra ser doutrinado ideologicamente partidário, tá? \\
\hline
\end{tabular}

Conforme foi levantado, é de se ponderar sobre a preocupação da mãe e do irmão a respeito de uma atmosfera de rivalidade em sala de aula, o que é um receio genuíno. Em uma pedagogia crítica, afinada com os pressupostos de Freire, a ética e a responsabilidade são diretrizes essenciais para uma prática pedagógica libertadora. A questão é que as falas da mãe e do filho apresentam diversas instâncias de entextualização de discursos apregoados pelo ESP, ou seja, refletem todo um conjunto de ideologias de ameaça, de desconfiança e de rivalidade entre professor e aluno alimentadas pelo programa, como vem sendo problematizado neste estudo (PENNA, 2017). Desse modo, a professora é construída como uma aliciadora de mentes ("tentando né, mexendo na cabecinha dele, de criança e adolescente entre treze e quinze anos né”, 1.1920), uma rival ou inimiga dos alunos por discordar da ideologia política e cristã dessa família (“porque ela tá lá pra ensinar a matéria. Ela não tá lá pra fazer campanha política e mesmo nós que somos cristãos de direita, né, nós procuramos respeitar a opinião das pessoas", 1 . 23-25). Em suma, uma prática profissional dita de respeito é ressignificada como expectativa de subserviência docente, sem licença para discordar.

Se a discordância é entendida como rivalidade, é porque a noção de ensino aqui segue a cartilha do ESP, sendo entextualizada como transferência e congruência de ideias ("E escola é o lugar pra o aluno ser ensinado, né, intelectualmente, não pra ser doutrinado ideologicamente partidário, tá?", 1. 25-26). O medo dessa família não é infundado, sendo parte de um alinhamento ideológico ao discurso terrorista propagado pelo programa. Ora, essa mãe relata já ter buscado orientação da direção da escola ("E eu já falei com a diretora da escola ano passado por duas vezes. Eu to gravando esse vídeo e eu vou tomar as providências legais contra essa professora", 1. 20-22), mas sinaliza uma preferência pela linha coercitiva e punitiva oferecida pela plataforma do ESP: criminalizar a discordância.

Portanto, a arma discursiva do programa é a do acirramento da discordância, sendo supostamente ético sugerir que um posicionamento docente discordante é uma ameaça, sobretudo se inclinado à esquerda, como ilustra o caso em tela. A professora passa a ser ressignificada como inimiga dessa aluna, na medida em que a divergência de ideias é rivalizada em sala de aula. Assim, o ESP reconstrói alunos como blocos 
fechados, não como seres humanos complexos, reflexivos e sociais (FREIRE, [1970] 2006; [1996] 2013; MOITA LOPES, 2006; hooks, 2013).

\section{Eixo 4 - O crime é discordar do "meu partido": uma ética censuradora}

\begin{tabular}{|c|c|l|}
\hline Mãe & 27 & Então to gravando esse vídeo, espero que chegue. Eu vou marcar aí o Jair \\
& 28 & Bolsonaro, eu espero que chegue às pessoas e os pais desses alunos que tome \\
& 29 & cuidado e não podemos aceitar isso: professor que fica incitando o ódio \\
& 30 & contra a bíblia, contra cristãos e principalmente contando mentiras, mentiras \\
\hline Irmão & 31 & Eu tenho provas... \\
\hline Mãe & 32 & Eu tenho provas. Quero que ela ache um discurso que Bolsonaro disse que \\
& 33 & vai pegar e vai mandar todos os negros pra senzala de novo, trazer a \\
& 34 & escravidão de volta pro Brasil, e que mulheres tá liberado pra ser estupradas. \\
& 35 & Isso aí é uma mentira, tá? E que os homens vão tá liberado pra espancar... \\
\hline Irmão & 36 & ...espancar... \\
\hline Mãe & 37 & ...as mulheres e falou um monte de bobagens, como é a característica das \\
& 38 & pessoas de esquerda. Como eles não têm cérebro, eles acham que as outras \\
& 39 & pessoas não têm também, né, que eles podem doutrinar, que eles podem \\
& 40 & fazer o que eles quiser. Então, deixo aqui a minha indignação contra essa \\
& 41 & professora que se diz professora, né, isso não pode acontecer. \\
\hline Irmão & 42 & E não se preocupe que nós temos prova disso. Nós temos provas que ela \\
& 43 & falou isso e, querem saber, nós vamos mostrar essa prova aí. \\
\hline
\end{tabular}

Nesse último eixo analítico, a tentativa de criminalizar a discordância como estratégia panfletária pró-Bolsonaro assume a tônica discursiva. Em sintonia com a discussão proposta por Espinosa e Queiroz (2017), não podemos esquecer que membros da família Bolsonaro e correligionários declaradamente cristãos são congressistas apoiadores da pauta do ESP. Tais vozes são entextualizadas e defendidas no discurso da mãe ("Eu vou marcar aí o Jair Bolsonaro, eu espero que chegue às pessoas e os pais desses alunos que tome cuidado e não podemos aceitar isso: professor que fica incitando o ódio contra a bíblia, contra cristãos e principalmente contando mentiras, mentiras", 1. 27-30). Aqui, é possível apontar também uma contradição no discurso da mãe, cujos efeitos favorecem os propósitos do ESP. Se a conduta da professora é posta em xeque sob a acusação de panfletagem partidária, por que a mãe não assume a própria postura pela qual luta? Em outras palavras, por que a mãe não rechaça terminantemente qualquer discussão consoante a partido x ou y? $\mathrm{O}$ que se verifica é que ela escolhe adotar um posicionamento de defesa de um dos lados da equação - desse modo, panfletária (da linha 27 a 41, com destaque para "Eu vou marcar aí o Jair Bolsonaro") - em vez de afirmar, por exemplo, que não irá assumir defesa de nenhum partido político, como ela esperava da conduta da professora. Portanto, a professora é ressignificada como uma mera instrutora de ideias prontas em sala de aula, sendo a ela também censurado o 
direito de posicionar-se sobre questões políticas. Torna-se lícita apenas à família a educação de seus filhos (PENNA, 2017).

Logo, o modus operandi do ESP aqui aproxima-se de uma lógica de homogeneização e de censura da prática docente. Sua plataforma não cumpre um fim reflexivo, (auto)crítico e apaziguador. No lugar de buscar um diálogo saudável e conciliador entre responsáveis e professores, esse canal de denúncias recorre a discursos opressores que, longe de atenuarem, intensificam a atmosfera de medo, de desorientação e de desinformação (CIAVATTA, 2017) de famílias sobre a formação educacional de seus filhos em territórios escolares.

\section{8) A propósito de (anti)ética e de caminhos de intervenção}

Diante da discussão proposta, cabem algumas indagações sobre os sentidos de ética com os quais o ESP opera para construir a prática dessa professora de História como “antiética". Que espécie de ética rivaliza os territórios da escola e da família? Que conceito de ética coloca o professor sob a mira de uma câmera e o acusa de crimes ideológicos sem embasamento, pesquisa e responsabilidade? Que tipo de atmosfera sócio-educacional essa prática de vigilância fundada no medo e na desinformação (re)produz? Como podemos resistir?

Neste locus investigativo, os sentidos de ética analisados indexicalizam uma orientação normativa (MARCONDES, 2007), isto é, fortemente entextualizando fundamentos dogmáticos e impositivos, fundados no medo, na acriticidade, na ameaça, na censura, com linhas de ação bem definidas e articuladas para o favorecimento de uma linha política de direita ultraconservadora. Todavia, percebo uma grande potencialidade de confrontar alegações de "neutralidade", de "defesa da família", de "apartidarismo" quando criamos maior entendimento acerca de processos de circulação, contextualização e recontextualização de discursos em nossas interações (BAUMAN; BRIGGS, [1990] 2006; BLOMMAERT, 2005).

Tal suporte analítico expõe os diversos atravessamentos discursivos que percorrem nosso modo de pensar e de agir, dando proeminência à linguagem como prática, não como representação de um estado de coisas. Além disso, na era da pósverdade (CIAVATTA, 2017) - em que opiniões fundadas no signo da desinformação dominam o debate público —, é vital que a academia não se feche em muros intransponíveis. Pelo contrário, é necessário fazer cada vez mais pesquisas, mais 
debates, mais aulas abertas à comunidade, maior uso das redes sociais para ampla divulgação e convite para eventos acadêmicos, maior abertura interpessoal em prol de uma aliança entre a universidade e a sociedade. Sobretudo, em tempos de projetos de lei que pretendem esfacelar uma livre, democrática e crítica interlocução de ideias.

Considero urgente uma produção de rede de epistemologias que resistam e desafiem as ideologias do medo, da acriticidade, da ameaça e da censura disseminadas pelo programa Escola Sem Partido. Para tal tarefa, é preciso que afirmemos um compromisso com uma agenda ética assumidamente tomadora de escolhas antihegemônicas (MOITA LOPES, 2006).

\section{Referências}

AGÊNCIA ESTADO. Em 2 meses de governo, mídia é alvo de Bolsonaro no Twitter a cada 3 dias. Correio Braziliense, 12 mar. 2019. Disponível em: <https://www.correiobraziliense.com.br/app/noticia/politica/2019/03/12/interna_politica ,742353/midia-e-alvo-de-bolsonaro-no-twitter-a-cada-3-dias.shtml>. Acesso em: 10 abr. 2019.

BAUMAN, R; BRIGGS, C. Poética e Performance como perspectivas críticas sobre a linguagem e a vida social*. Ilha Revista de Antropologia, Florianópolis, v. 8, n. 1, p. 185-229, jan. [1990] 2006.

BLOMMAERT, J. Discourse: a critical introduction. In: Cambridge: Cambridge University Press, 2005.

CANDAU, V. M. Multiculturalismo: diferenças culturais e práticas pedagógicas. Petrópolis: Editora Vozes, 2008.

CARVALHO, Olavo de. "Viva Paulo Freire!". Escola sem Partido. Disponível em: <http://escolasempartido.org/artigos-top/334-viva-paulo-freire>. Acesso em: 10 abr. 2019.

CIAVATTA, M. Resistindo aos dogmas do autoritarismo. In: FRIGOTTO, G. (org.) Escola "sem" Partido: esfinge que ameaça a educação e a sociedade brasileira. Rio de Janeiro: UERJ, LPP, 2017. p.7-16.

ESCOLA SEM PARTIDO. Flagrando o doutrinador. Disponível em: <http://escolasempartido.org/flagrando-o-doutrinador>. Acesso em: 10 abr. 2019.

Flagrante de doutrinação em escola de Santa Catarina. Disponível: <http://www.escolasempartido.org/corpo-de-delito-categoria/671-flagrante-dedoutrinacao-em-escola-de-santa-catarina>. Acesso em: 10. abr. 2019.

Objetivos. Disponível em: <http://www.escolasempartido.org/objetivos>. Acesso em: 10 abr. 2019. 
ESPINOSA, B. R. S; QUEIROZ, F.B. C. Breve análise sobre as redes do Escola sem Partido. In: FRIGOTTO, G. (org.) Escola "sem" Partido: esfinge que ameaça a educação e a sociedade brasileira. Rio de Janeiro: UERJ, LPP, 2017. p. 49-62.

FABRÍCIO, B. F.; MOITA LOPES, L. P. Discursos e vertigens: Identidades em xeque em narrativas contemporâneas. Veredas (Rio de Janeiro), Juiz de Fora, v. 6, n. 2, p. 1129, jul./dez. 2002.

FREIRE, P. Pedagogia do oprimido. Rio de Janeiro: Paz e Terra, [1974] 2011.

Pedagogia da autonomia: saberes necessários à prática educativa. Rio de Janeiro: Paz e Terra, [1996] 2013.

G1. Após postar vídeo com pornografia, Bolsonaro pergunta o que é 'golden shower'. G1, 06 mar. 2019. Disponível em: <https://g1.globo.com/politica/noticia/2019/03/06/apos-postar-video-com-pornografiabolsonaro-pergunta-o-que-e-golden-shower.ghtml>. Acesso em: 10 abr. 2019.

GOIS, Antônio. Educação: escola sem partido é a principal bandeira de Jair Bolsonaro. O Globo, 28 out. 2018. Disponível em: <https://oglobo.globo.com/brasil/educacaoescola-sem-partido-a-principal-bandeira-de-jair-bolsonaro-23193686>. Acesso em: 10 abr. 2019.

hooks, b. Ensinando a transgredir: a educação como prática da liberdade. São Paulo: Martins Fontes, 2013.

KUMARAVADIVELU, K. A linguística aplicada na era da globalização. In: MOITA LOPES, L. P. (org.) Por uma linguística aplicada indisciplinar. São Paulo: Parábola Editorial, 2006. p. 129-148.

MARCONDES, D. Textos básicos de ética: de Platão a Foucault. Rio de Janeiro: Zahar, 2007.

NAGIB, Miguel. Quem somos. Disponível em: <http://www.escolasempartido.org/quem-somos>. Acesso em: 10 abr. 2019.

MOITA LOPES, L. P. Linguística aplicada e vida contemporânea: problematização dos construtos que têm orientado a pesquisa. In: MOITA LOPES, L. P. (org.) Por uma linguística aplicada indisciplinar. São Paulo: Parábola Editorial, 2006. p. 85-107.

PENNA, F. A. O Escola sem Partido como chave de leitura do fenômeno educacional. In: FRIGOTTO, G. (org.) Escola "sem" Partido: esfinge que ameaça a educação e a sociedade brasileira. Rio de Janeiro: UERJ, LPP, 2017. p. 35-48.

TRIBUNAL SUPERIOR ELEITORAL. Propostas de governo dos candidatos ao cargo de Presidente da República. Disponível em: <http://www.tse.jus.br/eleicoes/eleicoes-2018/propostas-de-candidatos>. Acesso em: 10 abr. 2019. 


\title{
PROBLEMATIZING THE MEANINGS OF ETHICS OF "SCHOOLS WITHOUT POLITICAL PARTIES": A BRIEF ANALYSIS OF ENTEXTUALIZATIONS BY THE PROGRAM VIS-À-VIS TEACHING PRACTICE
}

\begin{abstract}
The present paper problematizes the meanings constructed by the allegedly non-partisan program "Schools without Political Parties" in relation to the exercise of ethical teaching practice. In doing so, I align myself with a sense of ethical-political and antihegemonic education (FREIRE, 2006; 2013; MOITA LOPES, 2006; hooks, 2013) within the post-truth era (CIAVATTA, 2017). My qualitative analysis focuses on language in use, understood here as a textual phenomenon, constantly intertwined with processes of entextualization (BAUMAN; BRIGGS, 2006). Results indicate that the program shares meanings of ethics founded on fear, non-critical thinking, threat and censorship for the benefit of the party line.
\end{abstract}

\section{Keywords}

Ethics. Education. Entextualization. School without Party. Post-Truth Era. 